\title{
Milestones In Turkey's Long Way To European Union Membership
}

\section{Gökhan Turhan}

Suleyman Demirel University, gokhanturhan32@gmail.com

Şakir Hüseyin Aksöz

Suleyman Demirel University, sakiraksoz@mynet.com.tr

Ferdi Akbiyik

Suleyman Demirel University, ferdiakbiyik@hotmail.com

\section{Doi:10.5901/mjss.2013.v4n11p781}

\section{Abstract}

The membership process of Turkey has been carried out since 1959 when Turkey first applied to join what was then called the European Economic Community. This process had profound influence on Turkey in many fields such as economy, social life, international policy, education etc. The first agreement signed between Turkey and European Union was "Ankara Agreement" which took place in 12 September 1963. This agreement envisaged establishment of customs union, which was aimed at integration of Turkey and European Economic Community in three main phases. Following this agreement additional protocols were signed. The year 1987 was another turning point for the process that Turkey applied for full membership on this date. In Helsinki Summit, which took place in 1999, Turkey was accepted as a candidate country. Five years later, in 2004 Turkey realized an important step on the way to becoming a full member. In 2004 European Union Member States decided that negotiations with Turkey could be initiated. The negotiations are still carried out. All of the agreements and protocols in the process required Turkey perform new policies which affect the society in many fields.In this study, milestones in Turkey's long way for European Union Membership will be examined chronologically.

Key Words: EU, Turkey, Membership Process, Customs Union, Ankara Agreement.

\section{Introduction}

The relations between Turkish people and the European civilization have a deep and long history. Remarkable relations date back till the Seljuk Empire times then it continues with the Ottomans. The Otoman Empire was recognized as a European state with the Declaration of Paris in 1856 (Eldem, 2005). After Ottoman Empire's collapse, Turkish Republic was founded and its fundamental aim was to reach modern civilizations level.

The way of reaching modern civilizations level was to internalize developments experienced in the west without destroying our own values. Till the end of 1950s, the relations ran at an idle, however 1959 was a landmark in view of Turkey's relationships with Europe. In this year the Turkish government applied to European Economic Community to be an associate member.

The second important date is 1963. The Turkish government signed the Ankara Agreement with the EEC. It was the first financial protocol between the community and Turkey (Euractive 2004) and constituted legal foundations of the membership process. After Ankara Agreement, another important component in the relations was The Additional Protocol of 13 November 1970 which meant Turkey would be a part of customs union step by step. After the long period of negotiations, protocols and different obstacles which took nearly thirty years, in 1995 Customs Union Agreement was signed. With this agreement, Turkey became a full member of the Customs Union in 1 January 1996 and almost 60 per cent of Turkey's trade is now with European states.(Ulgar, 2009)

Between the Additional Protocol (1970) and Customs Union Agreement (1995), 1987 is another important date when Turkey applied to the Community for full membership, which was not a planned action.

1999 Helsinki Summit followed Customs Union Agreement and Turkey became a candidate country. After Helsinki Summit, another important date was October 2004 when the Commission presented the 2004 regular report on Turkey's 
progress towards accession and recommended the opening of accession negotiations with Turkey in this report (Pime Ministry Undersecretariat of Customs 2007). In October 2005 negotiations started and membership process took a new route.

\section{Ankara Agreement}

In July 1959, just after the foundation of the European Economic Community, Turkey applied to the community to join. Turkey had two main aims to apply; the first aim was not to be surpassed by Greece, which applied before Turkey, in trade because Turkey and Greece had similar agricultural products and if Greece had joined the community, it would have a lot of commercial advantages compared to Turkey. The second aim was to internalize western developments and innovations in all fields of life. With the declaration of republic, Turkey made its preference towards becoming a contemporary western state and joining the community was important to realize this aim.

In response to Turkey's application, EEC suggested establishing an association until Turkey's standards reached a satisfactory level. Following negations resulted in the signature of Ankara Agreement which was signed on 12 September 1963. In the framework of this agreement, Turkey would be a full member state, but before full membership, customs union would be established in three phases to secure Turkey's integration into the community. (Hatipoğlu, 2004)

Ankara Agreement aimed at bringing the parties closer together in economic and trade matters. In this direction, EEC offered financial assistance to Turkey. Under the first Financial Protocol which lasted from 1963 to 1970, the EEC provided Turkey 175 million ECU. The trade concession which the EEC granted to Turkey under the form of tariff quotas proved not to be as effective as expected, however, the EEC's share in Turkey imports rose from 29\% in 1963 to $42 \%$ in 1972. (www.abgs.gov.tr)

Another issue which should be mentioned under this title is that although Ankara Agreement envisaged the free circulation not only of goods, but of persons, services and capital between parties, this has never been performed and Turkey still struggle to abolish visa barrier between the parties of the Ankara Agreement.

\section{Additional Protocol}

The Additional Protocol, which was signed on 13 November 1970, explained in a detailed way how the Customs Union would be established. According to this protocol, EEC would abolish tariff and quantitative barriers to its imports from Turkey, while Turkey would do the same in accordance with a timetable containing calendars set for 12 and 22 years. During this process, EEC asked Turkey to harmonize its legislation with that of EEC. In addition, the Additional Protocol envisaged the free circulation of persons between the parties in the next 12 to 22 years. $92 \%$ of our agricultural exports benefited from this regime. Additional Protocol means passage to second phase mentioned in Ankara Agreement. (Karluk, 2011)

\section{Application For Full Membership}

Military intervention, which took place on 12 September 1980, caused the relations between Turkey and EEC to come to a halt. After the freeze stage between parties, in 1983 multiparty elections in Turkey were carried out and then Turkey started to normalize its conditions. In the positive atmosphere after the military intervention, Turkey applied to EEC to become a full member state. This application was not planned in the process plan written in Ankara Agreement. As basis for the application, Turkey showed EEC Treaty's 237. Article which declares any European Country can apply for full membership. EEC's response to the application was to wait until Turkey had more favorable economic, social and political standards. Although this unplanned full membership application did not work, it certainly revived the relations between parties. (www.euroactive.com)

\section{Customs Union}

As planned in Additional Protocol, necessary regulations were carried out to achieve Customs Union in 1995. After 2 years-long preparation process, on 5 March 1995, Customs Union Agreement was signed. It came into force on 1 January 1996. This means passage to the last phase mentioned in Ankara Agreement. Customs Union has a lot of advantages at commercial issues for both sides. It also envisages free circulation of persons, goods, services and 
capital. However, free circulation of persons was not realized in practice and it is still a negotiation matter between Turkey and EU. (www.mfa.gov.tr)

\section{Helsinki Summit}

Helsinki Summit was held on 10-11 December in 1999. In this meeting, Turkey's candidate position was approved and it was stressed that Turkey had equal position with other candidate countries. What required this explanation was the offer to Turkey to be a conditional candidate and member country, which was strongly opposed by Turkey.

As a result of the approval, Instrument of Accession was signed between parties in 2001 and reviewed in the years 2003, 2005, 2006 and 2008. In the framework of Instrument of Accession, National Program was formed and updated in 2003, 2005 and 2008. During these years, many adaptation laws concerning human rights, freedoms of speech and thought, constitutional and democratic rights were passed by Turkey.

\section{Negotiations Start}

17 December 2004 was another milestone in Turkey's accession to European Union. On this date European Union decided Turkey met the requirements of European Union's political criteria and membership negotiations would be started on 3 October 2005.

Negotiations have been continuing since 3 October 2005. Till now 13 articles have been started to be negotiated and one of them was completed temporarily.

\section{References}

Eldem E., Ottoman Financial Integration with Europe: Foreign Loans, the Ottoman Bank and the Ottoman Public Debt, Boğaziçi University, Department of History

Euractiv, http://www.euractiv.com, the independent media portal fully dedicated to EU affairs, 2007

Hakim A., Middle East Needs Turkey's EU Membership, The Journal of Turkish Weekly Opinion, 02 October 2005

Hatipoğlu M. M., Avrupa Birliği: Çağdaş Uygarlı̆ı̆ Yolu mu, Ulusal Egemenliğin Sonu mu? ( Is the EU way to modern civilizations or the end of national sovereignty?) Symposium, 08-09.11.2004, Istanbul Hacettepe University Publication

Karluk, Rıdvan. Avrupa Birliği, Beta Yayınevi, 2011. Ankara.

Ministry of European Union, www.abgs.gov.tr

Ministry of Foreign Affairs, http://www.mfa.gov.tr/agreement-establishing-an-association-between-the-european economic-communityand-turkey-signed-at-ankara -september-1 -1963 .en.mfa, 2008

Ulgar F. G., Advantages and Disadvantages of EU Membership for Turkey, M.A. Thesis, 2009, Bahcesehir University, İstanbul. 